EARLY FALL RECORDI OF SNOWY OWL. - On August 23, 1958 , a Snowy Owl was observed along with myriads of waterfowl on the east shore of Goose $\mathrm{Lake}$ about seven miles ea $\mathrm{s} t$ of Harris, Saskatchewan. The owl was sitting in a patch of sedge, making a striking contrast against the green background. Apparently it was an immature bird as platches of down were still visible especially about the head. Flushed, the owl flew off toward the lake and läter was seen perched on an overturned stump several yards from shore. Perhapis this early arrival foretells bard winter ahead, maybe the lemming population has tumbled, or more likely it is just a wandering young owl, -Bob Folker, Wildlife Ecologist, D.N.R.

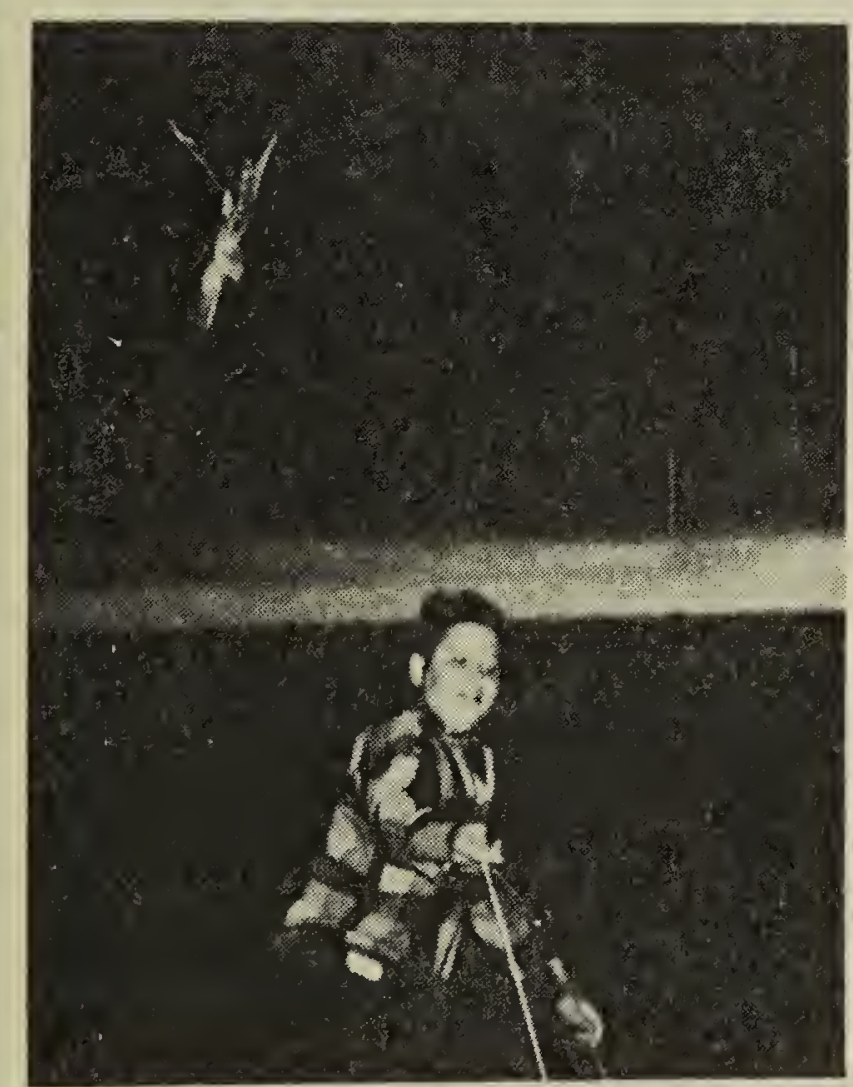

Photo by $F$. W. Lahrman "Thor" (Pigeon Hawk) diving at the lure swung by Howard Erickson, member of the Sask. Falconry Asscciation.

\section{Resolutions Passed Urging Protection of Birds of Prey}

MOOSE JAW NATURAL HISTORY SOCIETY-On September 12, 1958 , an open meeting of the society was held to arouse interest in the birds of prey. Visitors included members of the Mocse Jaw Fish and Game League, the South Saskatchewan Wildlife Association, Wildlife Branch D.N.R., Regina Natural History Society, and the Saskatchewan Museum of Natural History. At the Saskatchewan Training School grounds Richard Fyfe and members of the Saskatchewan Falconry Association gave an exhibition of falconry. The group then gathered in the hall for a short talk by Mr. Fyfe on the history of falconry and the main address of the evening on the "Role of Hawks and Owls" by John A. Livingston of Toronto, executive director of the Audubon Society of Canada. Mr. Livingston's remarks gave rise to numerous questions and a discussion followed on the advisability of introducing legislation in Saskatchewan to protect birds of prey. A motion was made by W. J. Beamish, president of the Moose Jaw Fish and Game League and also a member of our society that "All hawks, owls, eagles and ospreys be protected, except that the owner of pouitry or other domestic animals (including game farms) and the members of his immediate household and his bona fide employee, may destroy by shooting, any of these birds which is in the act of doing real damage to the said poultry or other domestic animals." The motion was passed with no dissenting vote.Mrs. F. B. Taylor, Secretary, Moose Jaw Natural History Society.

SASKATCHEWAN NATURAL HISTORY SOCIETY - At the annual meeting of the society in Saskatoon, October 18, 1958, a significant part of the programme wias devoted to the question of the protection of hawks and owls. The main address of the evening was given by John A. Livingston, who restated the strong case he had made for the birds of prey at the Moose Jaw meeting. He defined the term "balance of nature," showing the interdependence of all animal and plant life and explaining how predatcrs play a role in this "swinging" balance. In conservation education, he said, liss the only hope of removing the age-old stigma atitiched to birds of prey. The Audubon Society cf Canada is therefore making every effort to promote education about the role of the hawk and owl in nature's balance, as well as legislation to protect them. Following $\mathrm{Mr}$. Livingston's address, the aiesthetic value of the birds of prey was convincingly shown in the kodachrome shots of C. Hampson and the movies of E. Jones who came from Edmonton at their own expense to speak for the hawks and owls. Richard Fyfe and members of the Saskatchewan 
Falconry Association argain showed the beauty of their trained falcons as they flew them for the audience.

When the resolutions were brought in at the afternoon business session, the following resolution was adopted unanimously by the meeting: "That all hawks, owls, and eagles be protected, except that a farmer, landowner, or game warden may destroy by shooting hawks or owls which are in the act of doing real damage to managed game, poultry, or domestic animals on the land he owns or occupies."

\section{WHIP-POOR-WILL O B S ER V E D} AT SPIRIT LAKE.-A Whip-poorwill was present at Spirit Lake during early June this year. I first heard it on June 4 when it sang in a yard for some time in the late evening. Although this was the first time that I had heard this species, its call was distinctive enough to be identified readily. I heard it almost every evening until June 15 . The first evening I saw it in flight, but it was too dark to note any markings. This species is rare in the district at present, although in Stuart Houston's Birds of the Yorkton District the late John Gunn is quoted as finding it commen from 1888 to about 1908.-Bill Anaka, Spirit Lake, Sask.

\section{DRY WEATHER AFFECTS NEST- ING OF BARN SWALLOWS.}

Because of the unprecedented dry seascn this year an unusual condition developed and prevailed which affected all birds in this locality that use mud for their nests. Barn Swallows and Robins were particularly hard hit by this lack of building material. I observed one Barn Swallow nest that was started after a light shower and left unfinished ior over a 'nonth before another light shower produced enough mud to finish this nest. Unfo-tunately this nast fell off after the cggg were iald because the mud used was too Ars. Another nest under cbservation is just now (Sept. 15) raising its second breod.-Anthony Hruska, Gerald, Sask.

COMMENSAL FEEDING OF EVENING GROSBEAK A N D HERMIT TRUSH.-Near my kitchen window srow several large pincherry trees, which are 12 to 17 feet in height. This year, as usual, these trees were heavily fruited. Between 7 and 8 o'clcck in the morning of September 24, four Hermit Thrushes were seen picking up and eating the red pulp of the cherries as it was continually dropped by two Evening Grosbeaks that were feeding high up among the branches. The Grosbeaks were removing the pulp before cracking the stone which also was dropped before they swallowed the kernel. Several times the trushes were seen to catch the pulp as it fell, in smart flycatcher fashicn. Competition for this food appeared to be keen amongst the Hermits as they continually chased one another from beneath the trees, but quickly returned to resume feeding.-Maurice Sitreet, Nipawin, Sask.

RECORD OF PARULA WARBLER AT EMMA LAKE, JUNE, 1939.On June 27, 1939, Farley Mowat and F. Banfield observed a male Parula Warbler at Emma Lake. The bird was not collected but was under observation for about five minutes and wlas clearly seen at distances of no more than fifteen feet. As there was no other record for the province at the time, this record was not published in Mowat's "Notes on the Birds of Emma Lake, Saskatchewan" (Can. Field-Nat. 1947, pp. 105-115). - C. S. H.

\section{"Trouble" on the Cover}

The cover photo of this Blue Jay shows Richard Fyfe's trained Prairie Falcon "Trouble." Recently an unexpected tribute wias paid to "Trouble" by Beatrice Ione Perry of Loveland, Colorado, who sent these lines to Mr. Fyfe:

A. young prairie falcon belonging to Fyfe

Was caught at Big Muddy too early in life

To have any hawk-fun before he was tamed-

He can't avoid Trouble, for Trouble he's named!

But sometimes, while pensively watching his toes.

He sees he toes in, so wherever he goes,

You can tell by the fiery look in his eye

He's worried 'bout something, but will not say die

Till he fools all his tamers-the hounds and the scamps-

For he knows he'll wind up with his picture on stamps.:

Reference to the conservation stamps sold in the U.S. by the $\mathrm{Na}-$ tional Wildlife Federation. 